\title{
Incorporating sub-national Brazilian agricultural production and land-use into U.S. biofuel policy evaluation
}

\author{
Miguel Carriquiry, Amani Elobeid, Jerome Dumortier, and Ryan Goodrich
}

October 4, 2018

\begin{abstract}
We estimate emissions from indirect land-use change associated with U.S. corn ethanol production by using the updated CARD/FAPRI global agricultural outlook model which incorporates sub-national landuse modeling in Brazil and endogenous crop yield-price relationships. Emissions estimates are 9.7-23.9 $\mathrm{g} \mathrm{CO}_{2}$ per mega Joule $\left(\mathrm{MJ}^{-1}\right)$ which is consistent with other estimates. We compare the results of the current model to the 2008 model version. Using the data from the 2016 model in the 2008 model results in emissions of 23.2-32.2 $\mathrm{g} \mathrm{CO}_{2} \mathrm{MJ}^{-1}$. The addition of detailed modelling in Brazil, e.g., doublecropping, reduced estimates considerably and highlights the importance of continuous improvements in global agricultural models.
\end{abstract}

\section{Introduction}

In the last decade, there has been significant research and discussion about the land-use change emissions associated with U.S. biofuel expansion. In general, increasing crop demand for biofuel increases commodity prices because crops are competing for land. This competition for land leads to an increase in not only the price of the biofuel feedstock but also the prices of crops competing for the same hectare of land. Higher commodity prices encourage farmers to potentially convert grassland and forest to cropland. Given the global nature of agricultural markets, those price effects do not remain local but are transferred to the rest of the world leading to land-use change. Some early assessments of the life cycle greenhouse gas (GHG) emissions associated with increased production of U.S. biofuels find that a relatively large share of these emissions are related to land-use change in other countries, especially Brazil. The share of indirect land-use change emissions from Brazil in Dumortier et al. (2011) was 34\% in the market response scenario and $43 \%$ in the yield response scenario. ${ }^{1}$ In absolute terms, the land-use change emissions from Brazil alone were 142 and 111 million metric tons $(\mathrm{Mt}) \mathrm{CO}_{2}$-equivalent $\left(\mathrm{CO}_{2}\right.$-e) for the market response and yield scenario in Dumortier et al. (2011), respectively.

The regulatory impact analysis (RIA) conducted by the EPA in 2010 was compared to an updated analysis that uses the recent model improvements made to GTAP-BIO (Global Trade Analysis Project including biofuels) (USDA, 2017). The initial RIA attributed 39\% of overall lifecycle emissions to international landuse change whereas using updated model parameters and modeling strategies attribute only $16 \%$ of overall emissions to international land-use change. An initial study by Searchinger et al. (2008) finds land-use change emissions alone to be $107 \mathrm{~g} \mathrm{CO}_{2}$ per mega Joule $\left(\mathrm{MJ}^{-1}\right)$ compared to $96 \mathrm{~g} \mathrm{CO}_{2} \mathrm{MJ}^{-1}$ from gasoline. Two key characteristics of their study were high U.S. deforestation rates and no increase in global yields

\footnotetext{
${ }^{1} 43 \%$ of all countries that experience land-use change expansion.
} 
due to higher commodity prices. Those assumptions are highly influential in estimating emissions and subsequent research incorporating market responses, more realistic U.S. deforestation rates, and yield effects found estimates ranging from 14-65 $\mathrm{g} \mathrm{CO}_{2} \mathrm{MJ}^{-1}$ (Hertel et al., 2010; Dumortier et al., 2011; Taheripour et al., 2017b). More recent analysis by CARB using the GTAP-BIO model finds indirect land-use change emissions from corn ethanol to be $19.8 \mathrm{~g} \mathrm{CO}_{2} \mathrm{MJ}^{-1}$ and $21.8 \mathrm{~g} \mathrm{CO}_{2} \mathrm{MJ}^{-1}$ in the case of a scenario run and uncertainty analysis, respectively (CARB, 2014, 2015). ${ }^{2}$ Taheripour et al. (2017b) uses an updated 2011 GTAP-BIO database and allows for land-intensification. The authors calculate land-use emissions from corn ethanol to be $12 \mathrm{~g} \mathrm{CO}_{2} \mathrm{MJ}^{-1}$ using the new model and the updated database. In their analysis, the new database results in higher emissions than the 2004 database (which yield emission of $8 \mathrm{~g} \mathrm{CO}_{2} \mathrm{MJ}^{-1}$ under the new model) but is still lower than the estimates from the old model that range from 13.4 to $23.3 \mathrm{~g} \mathrm{CO}_{2}$ $\mathrm{MJ}^{-1}$. These estimates are in line with our estimates that incorporate intensification and the sub-national Brazil model.

Most of the existing analysis including the EPA's Renewable Fuel Standard (RFS) assumptions about indirect land-use change do not reflect recent data on deforestation rates in Brazil, which have been declining in the last 5 years (Arima et al., 2014). There is emerging evidence that the dynamics behind land-use change in Brazil may have changed since the EPA's analysis. For example, in recent years the Brazilian government has made a public commitment to reduce deforestation through stronger enforcement of deforestation and land-use laws already in effect (Nepstad et al., 2014). There seems to be evidence that agricultural producers in Brazil are intensifying crop and livestock production and incorporating new land at lower rates than in the recent past (Nepstad et al., 2014; Arima et al., 2014). In addition, the competition for forestry areas, and in particular between agriculture, pastures, and planted forests, is poorly understood and not explicitly taken into account in previous modeling exercises. If the dynamics of deforestation in Brazil have changed since the EPA's analysis, then the relationships, parameters, and results obtained by the EPA and others should be reevaluated. Of particular importance and recent interest is the potential for intensification of agricultural production and recovery of degraded pastures in Brazil to modify the past relationship between agricultural supply and deforestation rates (de Souza Ferreira Filho et al., 2015; Cohn et al., 2014).

In 2009, the European Union adopted a 10\% biofuel target for road transportation fuels (IFPRI, 2010, 2011). The legislation covers the types of land that can be used to cultivate biofuel feedstocks to restrict direct land-use change. Legislation has been implemented in 2015 to reduce the risk of indirect land-use change. The 2015 legislation did not directly address indirect land-use change because of the uncertainty surrounding the estimates (IFPRI, 2011). In evaluating EU biofuel policy using the GTAP-BIO model, IFPRI (2010) found annual emissions to be $17.73 \mathrm{~g} \mathrm{CO}_{2} \mathrm{MJ}^{-1}$ and $19.45 \mathrm{~g} \mathrm{CO}_{2} \mathrm{MJ}^{-1}$ for a business as usual and free trade scenario, respectively. Those emissions values are the sum of annual carbon release from forest biomass and annual carbon release from organic carbon in mineral soils. Over a 20 year lifecycle analysis, the marginal indirect land-use change emissions associated with corn ethanol in the EU were ranging from $54.11 \mathrm{~g} \mathrm{CO}_{2} \mathrm{MJ}^{-1}$ to $79.15 \mathrm{~g} \mathrm{CO}_{2} \mathrm{MJ}^{-1}$. Overall, it was found that ethanol from sugar beet and sugarcane lead to substantial GHG emissions. IFPRI (2011) finds emissions from EU biofuel policy to be $40 \mathrm{~g} \mathrm{CO}_{2} \mathrm{MJ}^{-1}$ and $38 \mathrm{~g} \mathrm{CO}_{2} \mathrm{MJ}^{-1}$ with and without trade liberalization, respectively. Note that those values include biofuel from a variety of feedstocks, i.e., corn, wheat, sugarcane, sugar beet as well as biodiesel feedstocks. The corn specific estimates are $10 \mathrm{~g} \mathrm{CO}_{2} \mathrm{MJ}^{-1}$. Valin et al. (2015) find that for an expansion of EU biofuels, the land-use change emissions for first generation corn ethanol is $14 \mathrm{~g} \mathrm{CO}_{2} \mathrm{MJ}^{-1}$.

A major purpose of this article is to compare results of a similar shock when applied to different versions of an agricultural outlook model so as to be able to identify how model modifications and improvements lead to better estimates of the implications of U.S. biofuel policies in terms of land-use, production, and GHG

\footnotetext{
${ }^{2}$ Land use change. https://ec. europa.eu/energy/node/75 accessed on 7 February 2018.
} 
emissions (especially in Brazil). The major focus of the paper is on the impacts of incorporating subnational production systems in Brazil on land use and production when facing increasing demand for agricultural products (affected by changes in U.S. biofuel demand). As pointed out by Egbendewe-Mondzozo et al. (2015), sub-national models of agriculture capture more details and take into account regional differences. On the other hand, without a price feedback effect, the regional models may result farmers being pricetakers. In our model, the integration of a sub-national model with a global agricultural model overcomes this issue.

To assess land-use change and GHG emissions, we use the CARD/FAPRI ${ }^{3}$ global agricultural outlook model ("CARD/FAPRI Model" henceforth). The objective of this paper is to include a sub-national model component for Brazilian agriculture ("Brazil Model" henceforth) into the CARD/FAPRI Model to better capture the economic and political drivers of agricultural production and deforestation in Brazil at the subnational level. Having the Brazil Model incorporated into the CARD/FAPRI Model allows us to simulate land-use change in the U.S., Brazil, and elsewhere triggered by an increase in U.S. biofuel production. The Brazil Model captures region-specific characteristics of crop production such as crop yields, production cost, livestock management, and land-use. The Brazil model has been used previously to evaluate a potential cattle tax in the U.S. but this paper represents the first time that it is used to evaluate biofuel policy (Dumortier et al., 2012). The CARD/FAPRI Model has been used in Dumortier et al. (2011) to evaluate carbon emissions from land-use and to allow for comparison with previous estimates, we compare the 2008 and the 2016 versions of the model for the same scenario and highlight differences and improvements to allow for comparison of the results.

\section{Literature Review}

To quantify the impacts of price changes on land- use, it is important to understand the balance between increased crop production due to intensification (e.g., higher yield per area harvested, expansion in multi cropping, returning unused cropland to crop production, using better seeds, improvement in water use efficiency, and so on) and extensification (i.e., expansion in cropland area). Given higher prices, the yield-price elasticity determines the increase in crop yields whereas the land-price elasticity determines the increase in area. For example, if the land-price elasticity is high (i.e., small changes in price result in large increases in area) and the yield-price elasticity is low then an increase in commodity prices induced by biofuel expansion will lead to greater land expansion. Additionally, the modeling of yields on newly converted land needs to be considered to understand the balance between intensification and extensification.

\section{Yield-Price Elasticity}

In most empirical work, yields are modelled as a function of time which implicitly assumes that yield improvements are entirely due to technological advances and unrelated to the crop's price. There are a number of studies that attempt to disentangle price response from technological growth. Searchinger et al. (2008) assume that any increase in yields due to higher crop prices is offset by lower productivity of lands converted to crop production. This assumption has three key components: yield response and area response are both positive and newly converted lands are marginal lands, i.e., their yield is lower than that of existing crop land.

\footnotetext{
${ }^{3}$ This is a model from the Center for Agricultural and Rural Development (CARD) and the Food and Agricultural Policy Research Institute (FAPRI) at Iowa State University.
} 
Keeney and Hertel (2009) review studies quantifying the yield-price elasticity for corn. After ruling out three of the estimates as irrelevant, ${ }^{4}$ they average four estimates for 1951-1988 data and estimate the yield-price elasticity for U.S. corn to be 0.25 . More recent versions of GTAP-BIO have departed from the assumption and have regionalized price-yield elasticities ranging from 0.175 to 0.325 (Taheripour et al., 2017a). In addition, double cropping and conversion of idle cropland have also been incorporated in the more recent models. Roberts and Schlenker (2009) note that crop prices are highly serially correlated over time and that if yields are driven by prices, they too will be serially correlated. Finding no statistically significant serial correlation, they conclude that yields are driven by weather and not prices. They argue that through inventory levels and storage, current demand is linked to the past weather (yield) shocks and this provides a means to exogenously shift demand and trace out current supply. Using standard two-stage least-squares they reach a total supply elasticity estimate between 0.105 and 0.106 which is entirely the area response. Huang and Khanna (2010) find a positive yield response by incorporating past weather shocks (along with other instrumental variables) used in Roberts and Schlenker (2009) into a dynamic panel generalized method of moments estimation and arrive at yield price-elasticities of $0.15,0.06$, and 0.43 for corn, soybeans, and wheat, respectively. Goodwin et al. (2012) examine whether there is an intra-seasonal yield response to price changes early in the growing season within a portion of the Corn Belt (Indiana, Illinois, and Iowa). They conclude that there is a small but statistically significant response of yields to price changes early in the growing season. They suggest a long-run yield-price elasticity of U.S. corn ranging from 0.19 to 0.27 for the aggregation of Illinois, Indiana, and Iowa and an elasticity ranging from 0.15 to 0.43 at the state level. This is in line with the estimate of Keeney and Hertel (2009), yet the authors have suggested that general equilibrium models such as the GTAP-BIO framework should use a yield-price elasticity greater than 0.25 because of the range of the state-level elasticities.

Generally speaking, the literature does not provide any consensus in regards to the magnitude of an appropriate yield-price elasticity and the existing evidence varies by econometric technique. Holding the level of aggregation constant, least-squares estimates tend to find an elasticity of larger magnitude than those from an instrumental variable estimation. High levels of aggregation such as the national level (or an estimate which includes all crops) tend to have estimates near zero regardless of the estimation method.

\section{Land-Price Elasticity}

All versions of the GTAP-BIO model employs a constant elasticity of transformation (CET) supply function to determine land-use. This model traces land use across uses by agro-ecological zones (AEZ) as a means of disaggregating regions to more accurately estimate land-use change. Barr et al. (2011) take advantage of the significant 2007 increase in prices in the U.S. and area fluctuations in Brazil to determine aggregate land-price elasticities for both countries. For the U.S., they use two methods to calculate the aggregate land price-elasticity. First, they use 3-year averages of acreage and expected returns for both the pre-boom years (2003-2005 or 2004-2006) and the boom years (2007-2009) and use the percent change in area and expected returns to find the elasticity. Second, they use a linear trend to forecast what 2007-2009 would have looked like and compare it to what actually occurred. Holding costs and expected yields constant, they are able to estimate the elasticity of expected net returns with respect to price to convert the land net returns-elasticity to a land-price elasticity. Using similar techniques but different time periods for Brazil, the authors arrive at estimates ranging from 0.38 to 0.477 in recent years. Those estimates indicate potentially large movements of carbon-rich forestry into cropland so the authors also calculate Brazil's elasticities with

\footnotetext{
${ }^{4}$ Keeney and Hertel (2009) reviewed Houck and Gallagher (1976), Lyons and Thompson (1981), and Choi and Helmberger (1993) and deemed the estimates by Houck and Gallagher (1976) and Menz and Pardey (1983) as irrelevant because they "incorporate a non-linear trend variable calibrated to adoption patterns (of high yielding varieties) observed in the mid-20th century."
} 
a pasture component included in the model and find that the elasticities now range between 0.007 and 0.082 . This suggests that additional lands would come primarily from pasture and not forests.

Huang and Khanna (2010) use two models to estimate land response in the United States. The first includes lagged area, weather, input and output prices, population density, and a time trend. The second also includes price and yield risk variables. Across these two models, the results are robust and provide area elasticities for total crop, corn, soybean, and wheat. They also find evidence that current crop area is positively related to the area in previous years. This supports the idea that there is a slow transition in landuse. See the section "Summary of Yield-Price and Land-Price Elasticities" in the supplemental materials for a summary of the elasticity estimates from previous literature.

\section{Yield Response to New Land}

As mentioned before, crop production increases can be achieved by either increasing area or yield. Whereas the increase in area is determined by the land-price elasticity and the increase in yield is determined by the yield-price elasticity, the yield response to new land connects both concepts. On one hand, higher prices will result in higher yields due to the yield-price elasticity but on the other hand, more land may result in a decrease in overall yield because newly converted cropland may not have the same yield as existing cropland, i.e., there may be a yield drag. Inherent in the concept of yield-price elasticity is the assumption that countries are currently not at their technological yield frontier (West et al., 2010). While relative elasticities matter in determining land-use impacts of biofuel-driven price increases, inherent in the magnitude of land conversion are the yields on newly converted land. This concept is different from the aforementioned yield-price elasticity which refers to an increase in yield (with no change in area) due to a price increase.

Lywood et al. (2009) comment on the relative importance of yield versus area growth in the U.S., the European Union (EU), Brazil, South America (excluding Brazil), and Southeast Asia. They state that total output growth in the U.S. and the EU is primarily due to yield growth whereas in the other countries/regions, $77 \%$ or more of the output growth is due to an increase in area. Keeney (2010) conclude that yield drag in a particular nation depends on that nation's distance from the technological frontier for a given crop. For example, data for Canada shows a distinct inverse relationship between corn area and yield whereas for Brazil, no such relationship exists. It is therefore very important to make assumptions at the regional level when modeling indirect land-use impacts. Brazil, in particular, had tremendous growth in corn yields and area following the Uruguay Round reform in 2000. This indicates a pattern of technological development that makes both the yield-price elasticity as well as the yield drag of newly converted lands difficult to estimate since the effects of incorporating new technologies would overshadow price responses or the ability to compare marginal and average yields. As the technology gap between Brazil and the U.S. continues to close, yield drag may be more apparent. For the time being, data on the trend in the U.S. and other developed nations indicates that the yields of newly converted agricultural lands will be lower than those of existing lands.

Over the past decade, disaggregation attempts into sub-national regions have been made in both the GTAP-BIO and FAPRI/CARD Model. GTAP-BIO has disaggregated all countries into agro-ecological zones while the FAPRI model has disaggregated the United States and Brazil. These attempts are meant to better judge the productivity of different regions as well as to have a better match between activities and ecosystems affected.

Following Keeney (2010), the early versions of GTAP-BIO model assumed that the average productivity of new cropland is about two-thirds of the average productivity of existing cropland, independent of the location. Taheripour et al. (2012) departed from this assumption. Using a process-based biogeochemistry 
model, these authors estimated regional values for this ratio by AEZ. They showed that using the estimated regional ratios reduces the land requirement for ethanol production by $25 \%$ compared to the results provided by Hertel et al. (2010).

\section{Drivers and Trends of Deforestation in Brazil}

The list of deforestation drivers is long and includes expansion of cropland and pasture, increases in livestock operations, population growth, human settlement, and development of (road) infrastructure, among others. See section "Deforestation in Brazil" in the supplemental information for the deforestation rates in the Amazon between 1988 and 2015. Since 2004, the annual amount of deforested area has been continually declining (Nepstad et al., 2014). This also coincides with volatility in commodity markets as well as stricter regulations on deforestation and improved monitoring and enforcement (Macedo et al., 2012).

Margulis (2004) provides an excellent review of deforestation causes. Historically, direct drivers of deforestation have been higher prices for agricultural commodities that led to an expansion of agricultural area into forest (Angelsen and Kaimowitz, 1999; Margulis, 2004; Diniz et al., 2009). At the same time, any decrease in land values resulted in the expansion of pasture area for grazing livestock (Faminow, 1997; Margulis, 2004). Medium and large livestock producers have especially contributed to this development (Margulis, 2004). There is a higher impact on deforestation and pasture where the land structure is dominated by large and medium farms (Aguiar et al., 2007). Besides agricultural and livestock expansion, there are other direct factors that result in deforestation. Multiple studies have identified the expansion of paved and unpaved roads (Angelsen and Kaimowitz, 1999; Kirby et al., 2006; Aguiar et al., 2007). The proximity to urban centers and roads is reinforced by the higher connectivity to the more developed parts of Brazil as well as general accessibility to markets (Aguiar et al., 2007; de Almeida et al., 2007). Besides their primary function, road expansion also facilitates deforestation practices, illegal occupation of land as well as land tenure conflicts. Deforestation from building more roads is not likely to continue to be a main driver in the future as Brazil is concentrating more on infrastructure improvements rather than expansion. Another main driver are rural settlements resulting from the agrarian reform policies in the 1970s. Those policies may be linked to deforestation at least in the period between 1995 and 2009, when the area of rural settlements and the rate of deforestation increased significantly in the Amazon. Population growth and the resulting growth in demand as a driving factor of deforestation have been identified by Faminow (1997), Kirby et al. (2006), Diniz et al. (2009), and Martins et al. (2010). Although the results by de Almeida et al. (2007) suggest that once the distance to the nearest road is included as an explanatory variable, the demographical category loses its explanatory power.

With respect to indirect drivers, Arima et al. (2011) points to the interrelationship between pasture and cropland in the sense that crop expansion can be linked to pasture conversion on the forest frontier. A similar result is established by Barona et al. (2010) that links pasture expansion in the interior Amazon to deforestation. In contrast to those studies, Macedo et al. (2012) find the possibility to increase soybean production without deforesting if there is a sufficient amount of previously cleared land. They have found little evidence that suggests expansion of soybeans into the Cerrado in Mato Grosso or adjacent Amazonian states. Decoupling livestock production from deforestation rates can lead to increased efficiency in beef production and reduced emission as shown by de Oliveira Silva et al. (2016).

The expansion of ethanol has also been cited as a main driver in deforestation. Lapola et al. (2010) find that carbon emissions from direct deforestation caused by the expansion of sugarcane ethanol and soybean biodiesel would require payback periods of 4 and 35 years, respectively. Those results suggest that soybean biodiesel contributes significantly to direct deforestation which is contradictory to the effects of soybean 
expansion found by Macedo et al. (2012). Indirect land-use change can be much lower or even zero with different assumptions on cattle intensification. Taking into account the indirect emissions, payback periods would increase to approximately 250 years. The authors note that assumptions on stocking rate are key and that an increase of 0.13 head per hectare could eliminate any indirect land-use change. Results by de Souza Ferreira Filho and Horridge (2014) suggest that for each hectare of sugarcane expansion, only 0.14 hectare comes from new land and 0.47 hectare comes from pasture. In light of those results, they suggest that policies limiting deforestation will have little effect on hindering biofuel production.

After deforestation, soybean production, livestock activities and timber production are cited as the main uses of land. The expansion of soybean production has impacted deforestation differently across time. In the early 2000s, soybean area expansion came from pasture (74\%) and forest (26\%) (Macedo et al., 2012). In the later 2000s, because of productivity growth (yield increases), production increases and over $90 \%$ of area expansion came from pasture areas. Two-thirds of pasture area converted by soybeans was deforested before 2000 (André Meloni Nassar and Granço, 2013). In terms of livestock production, until 2006, deforestation rates and cattle herd variation were strongly correlated. However, after 2006, intensification in terms of higher stocking rates, carcass weight and slaughter rate, resulted in a decline in deforestation rates despite an increase in livestock production alongside an increase in crop production and commercial forests. The signing of the Livestock Moratorium by the major Brazilian beef companies, as well effective public policies, also aided in reduction of deforestation rates.

Deforestation rates fluctuate considerably for many reasons including legislation. Two important pieces of legislation in 1989 aimed at registering and conserving parts of the Amazon and permanent preservation areas. In addition, they established buffer zones around water bodies and steep slopes which helped decrease deforestation rates in the late 1980s and early 1990s. However, 1995 witnessed significant levels of deforestation prompting the Brazilian government to implement stronger restrictions on deforestation in 1996. In 1998, the Environmental Criminal Law imposed significant fines and imprisonment for crimes against fauna and flora as well as for pollution and other environmental crimes. However, there were difficulties enforcing the law. Deforestation rates increased significantly again in 2004 and the Brazilian government launched PPCDAM (Plano de Ação para a Prevenção e Controle do Desmatamento na Amazônia Legal), which led to stricter enforcement against environmental crimes and corruption, as well as incentives for sustainable environmental practices. As a result, deforestation rates decreased noticeably between 2004 and 2007. Additionally, the "Soybean Moratorium" and the "Livestock Moratorium" were established in 2006 and 2009, respectively, by major producers with a commitment not to include in the supply chain any products coming from deforested areas of the Amazon biome. More recently, the National Policy of Climate Change (PNMC) in 2009 and the new Forest Code in 2011, are expected to further reduce deforestation rates over

time. PNMC's aim is to reduce deforestation rates to $3,900 \mathrm{~km}^{2}$ by 2020 . Rates have dropped significantly compared to the early 2000s because of the effective initiatives to reduce deforestation (Arima et al., 2014; Nepstad et al., 2014). Zycherman (2016) also points to other factor such as changes in cultural values and emerging forms of identities, as important in shaping new practices. There is evidence that some of the regulation and programs do not significantly contribute to the reduction in deforestation though (Alix-Garcia and Gibbs, 2017; Azevedo et al., 2017).

\section{Modelling Approach}

The analysis in this study is conducted through an augmentation of the well-established CARD/FAPRI Model which has been widely used to evaluate and inform policy and regulation (Dumortier et al., 2011; Elobeid et al., 2012, 2013). We follow closely a description of the model presented in Elobeid et al. (2012). 
Note that FAPRI at the University of Missouri (FAPRI-MU Model) maintains a detailed dynamic partialequilibrium agricultural outlook model which focuses on U.S. agriculture and policy. The FAPRI-MU Model has been updated and extended significantly over the years to better model U.S. agriculture including the modeling of the market for Renewable Identification Numbers (RIN) which is important for agriculture market and welfare estimates (Thompson et al., 2010; Meyer and Thompson, 2012; Egbendewe-Mondzozo et al., 2015; Thompson et al., 2017). The model used for this analysis is different because it is based on the version that covers global agricultural markets.

The CARD/FAPRI Model is an econometric, multi-market, non-spatial, partial equilibrium framework covering all major temperate crops, ethanol, sugar, biodiesel, dairy, and livestock products for all major countries. The modeling system allows for the interaction among the different markets to capture the demand for feed in the livestock sector and feedstock in biofuel production, substitution between agricultural products as well as competition for land (Figure 1). The model provides projections until 2021 of supply, demand, and prices for major agricultural commodities in yearly time steps by solving for a set of prices that equate supply and demand for all commodities and in all countries. The crops modeled are barley, corn, cotton, palm kernel, oats, peanut, rapeseed, rye, soybeans, sorghum, sugar beet, sugar cane, sunflower, and wheat. The CARD/FAPRI Model quantifies harvested area for those crops. For a more detailed description of the model, see Elobeid et al. (2012), and for references of studies that use this modelling system the reader is referred to Meyers et al. (2010).

While most of the components within the system are commodity models, Brazil and the United States are the two country models, which are comprised of their respective integrated agricultural markets within each country. Given that Brazil has widely varying ecosystems, the model is divided into 6 regions to capture the regional differences in infrastructure and available natural resources for agricultural production (see Figure 2). The regions are modeled to reflect differences in capabilities and consequences of expanding agricultural production such that the impacts of land-use changes derived from increasing demand for agricultural products can be more accurately analyzed. The Brazil component has been first integrated in Dumortier et al. (2012) to assess the effects of a potential cattle tax in the U.S. but has not been used to assess land-use change from an expansion of ethanol production.

As with the rest of the CARD/FAPRI Model, the Brazil Model includes all major crops, biofuels, and livestock interacting and competing for agricultural resources, in particular, land. The model provides projections of supply and demand variables and the amount of land allocated to each of the activities considered. The crops include corn (first and second crops), the soybean complex (including soybean meal, soybean oil, and biodiesel), the sugarcane complex (including sugar and ethanol), rice, cotton, and dry beans (multiple cropping, depending on the region). The modeled animal products are beef, pork, poultry, and dairy. In terms of land allocation, the area used by a given activity depends on its expected real returns in comparison to expected returns of activities that compete for the resource. Land used for pasture is explicitly modeled. Since not all of the regions considered are equally suited for different activities, the competition for land is contingent on the location. As such, not all activities compete with each other with the same intensity in all regions. Additionally, the model also allows for production costs, yields, and prices to vary by region. Spatial disaggregation of information on historical production activities and land availability, allows for the regional analysis of the relative profitability of productive activities. The local profitability will drive regional supply curves for crops and livestock operations and their associated land use.

Within the Brazil Model, allocation of agricultural land (cropland and pasture) is performed following two different approaches. First, for crops not in direct competition for land resources, either because they do not occupy land during the main growing season, or they are spatially separate, behavioral equations that project agricultural area are used. Wheat, barley, the second crop of corn, and the second crop of dry beans 
fall into this category. For these crops land allocation equations are mainly driven by real relative returns of the different activities.

Alternatively, a second group represents land using activities that compete for land resources in time and space. Land allocation for these activities is modeled using a two-step approach. The total area utilized for agricultural activities is determined first. An allocation of the area used for agriculture to the competing land uses is performed in a second step. Corn, soybeans, rice, cotton, dry beans, sugarcane, and pasture are modeled through this procedure. While the model solves for these steps simultaneously, it is clearer to present the procedures as if performed in steps.

In the spirit of the description being presented, the elasticities for agricultural activities (cropland and pasture) vary both by activity and region, and the numbers used in the model are presented in Table 1. The Center West Cerrados and the Amazon area present the highest responsiveness to changes in returns (as indicated by the first column) as a result, in part, of their relative land abundance. Regions with more severe land limitations, either because they were established earlier (and a higher proportion of the suitable land is already under production) or with resource constraints (more restrictive soils or climatic conditions), have lower area elasticities. As the table indicates, some crops such as soybeans and sugarcane are more responsive to changes in returns than staples for domestic consumption such as rice or in particular dry beans.

Table 1 also shows that the elasticities of pasture differ (as is the case of crops) by regions, indicating that pasture based livestock activities (beef and dairy production) are at the regional level. More broadly all supply side of the livestock sector (including poultry and swine production) is modeled at a regional spatial disaggregation.

An important feature of the model is that it allows for feedback between the pasture area and the size of the cattle herd. This is critical for internal consistency, as pasture is the major component in cattle diets, and at the same time cattle (and in particular beef) is the largest user of pastures. These feedbacks are modeled through the stocking rate (i.e., the number of heads per hectare of pasture), which is dependent on profitability. Profitability of beef and crops will interact to determine the number of hectares of pasture following the land allocation mechanism described before.

We briefly outline some major features of the ethanol component of the Brazil model as it will help understand the responses to the scenario to be analyzed in this paper. In Brazil, sugarcane is the main feedstock for ethanol. The land allocation mechanism described above determines the area planted to sugarcane by region based on the expected returns to agriculture and relative returns of sugarcane versus that of other land competing activities. While there is no market price for sugarcane in the model, returns to this activity is calculated based on the prices of sugar and ethanol, and the concentration of recoverable sugars in the cane. This later fraction, which is the feedstock for sugar and ethanol production is then allocated (shared out) to each of these activities depending on their relative price.

A demand side is needed to close the market. Domestic demand (for transport) for ethanol is both in anhydrous and hydrous forms. The anhydrous form is consumed in mandatory blends with gasoline (25\% ethanol) by both gasoline and flexible-fuel vehicles (FFVs). Hydrous ethanol is mainly used by FFVs but also by gasohol cars. Based on the relative price of these two fuels, FFV owners can choose between ethanol and blended gasoline. The domestic ethanol price follows the world price determined in the international ethanol component of the modeling system (equating global excess supplies and demands), which is adjusted by exchange rates and border policies.

As shown in Figure 1, the GHG model is an addition to the CARD/FAPRI Model to measure the emissions associated from land-use change. A previous version of the model has been used to assess GHG emissions from land-use change associated with biofuel expansion (Dumortier et al., 2011) and from changes in 
U.S. beef production (Dumortier et al., 2012). Note that a detailed description of the GHG model can be found in the supplemental materials associated with Dumortier et al. (2012) and we are only providing an abbreviated overview in this section. ${ }^{5}$

To estimate emissions from land-use change, we calculate the proportional change in each grid cell from a change in cropland and pasture. If crop production increases in a particular country, then crop production in each grid cell will increase proportionally. The land used for the expansion is based on the current fraction of forest and grassland in the cell. For example, if a cell contains $20 \%$ forest and $80 \%$ grassland, then an additional hectare of cropland will come from 0.2 ha of forest and 0.8 ha of grassland. A similar approach is used for pasture expansion which is determined based on the stocking rate for animal units. The proportionality assumption in our model is the result of the underlying data on carbon coefficients. The data set by Gibbs (2006) calculates a biomass carbon coefficient based on the IPCC Tier-1 method. They combine data on land-cover and climate regions (e.g., broad-leaved humid forest in tropical regions) with IPCC biomass carbon coefficients to calculate a weighted (by land cover) carbon coefficient for each grid cell. Because we are using those carbon coefficients, we also (implicitly) use the weighted average of carbon coefficients based on land-cover. We follow the approach by Gibbs (2006) to calculate minimum, mean, and maximum carbon coefficients based on land-cover and ecological zone. We merged the 2000 global land cover dataset ${ }^{6}$ with the FAO's Global Ecological Zones (GEZ) data ${ }^{7}$ to obtain a global GIS dataset on land cover in a particular ecological zone. Based on the information with regard the minimum, mean, and maximum coefficients provided by CDIAC ${ }^{8}$ we constructed three GIS maps of carbon coefficients.

There are two important changes to the proportionality assumption in the land-use change model. First, we assume that any cropland expansion in the U.S. is met with grassland and pasture, i.e., there is no deforestation occurring in the United States (Lark et al., 2015). Second, when reporting the GHG emissions from land-use change in Brazil, we present the results with and without the regional model. That is, we either use the aggregate number of total crop production in Brazil and proceed by the approach described above or we use the regional model which specifies the expansion of crop production and pasture in the six states.

\section{GHG Emission Scenarios}

In the subsequent sections, we are going to differentiate between the "CARD/FAPRI Model," the "data," and the "GHG Model." The CARD/FAPRI Model refers to the modelling framework to project agricultural production. The model generates output "data" in terms of crop production, area, prices, livestock, etc. The data is then used in the GHG model to evaluate land-use change to calculate emissions. We differentiate all those components for two years, 2008 and 2016. For example, using the 2016 (new) CARD/FAPRI Model to evaluate the increase of U.S. ethanol by $15 \%$ results in the 2016 data which is then used in the 2016 GHG Model. In Dumortier et al. (2011), the data from the 2008 version of the CARD/FAPRI Model was used in the 2008 GHG model to evaluate GHG emissions.

To evaluate the emissions from the corn ethanol expansion in the context of the new model, we will first present the results using the 2016 data and the 2016 GHG model that was used in Dumortier et al. (2012). In order to better understand the difference between the Dumortier et al. (2011) analysis and the current

\footnotetext{
${ }^{5}$ http://iopscience.iop.org/1748-9326/7/2/024023/media/er1429646suppdata.pdf

${ }^{6}$ See forobs.jrc.ec. europa.eu/products/glc2000/glc2000.php

${ }^{7}$ See ref. data . fao. org $/$ map? entryId $=2 \mathrm{fb} 209 \mathrm{~d} \theta-\mathrm{fd} 34-4 \mathrm{e} 5 \mathrm{e}-\mathrm{a} 3 \mathrm{~d} 8-\mathrm{a} 13 \mathrm{c} 241 \mathrm{eb} 61 \mathrm{~b} \& \mathrm{tab}=$ about

${ }^{8}$ CDIAC is the Carbon Dioxide Information Analysis Center whose data is now housed in the U.S. Department of Energy. A cross-walk between the carbon coefficients, ecological zone, and land cover can be found at cdiac.ess-dive.lbl.gov/ftp/ ndp017/table.html and cdiac.ess-dive.1bl.gov/epubs/ndp/ndp017/table_b.html\#table4
} 
version, we proceed in two steps: First, we take the 2016 data and use the 2008 GHG Model to evaluate emissions. In a second step, we take the 2008 data and use the 2016 GHG Model to evaluate emissions.

The scenarios associated with the 2016 data and the 2016 GHG model are analyzed along three dimensions: (1) incorporation of the sub-national Brazil model, (2) global pasture, and (3) carbon coefficients (minimum, mean and maximum). Presenting the results with and without the Brazil Model allows us to quantify the difference from including agricultural production at the sub-national level. If we calculate landuse change emissions without the Brazil Model, we simply aggregate the sum of area and production to the national level and use the method described in the previous section to calculate emissions. Including the Brazil Model uses the area and production in the six regions and has the advantage that it is not based on current land-use but takes future agricultural production and land-use dynamics explicitly into account given the characteristics of the region. The 2008 CARD/FAPRI model used only cropland to estimate emissions from land-use change while the current model incorporates pasture to account for changes in livestock as well. Thus, we estimate the current model with cropland only ("no Brazil model, no pasture") in a first step, then add pasture ("no Brazil"), and ultimately present the complete model. Gibbs (2006) differentiates between minimum, mean, and maximum biomass carbon estimates and we present our results for all estimates serving as a sensitivity analysis (Table 4)

\section{Results}

For the scenario, we shock the demand for ethanol in the U.S. with a $15 \%$ exogenous (and permanent) expansion. In order to analyze the impact of the increase in the demand for U.S. ethanol on Brazil, we first establish a baseline (business-as-usual scenario) against which the high U.S. ethanol demand scenario is compared. After introducing the shock, all the markets are allowed to react to the expanded ethanol demand. The initial impact of the shock will be an increase in the price of ethanol, which will discipline the demand expansion and lead to enhanced ethanol supplies. The impact of the derived additional demand for ethanol feedstocks, as well as the increased supply of ethanol by-products, will then be transmitted to the markets of other commodities and countries. As a result, we expect additional land being used for agricultural production, as well as higher crop prices as the competition for area intensifies. Because Brazil is the largest world ethanol exporter, and has a demonstrated potential to expand agricultural production, a large proportion of the adjustment can be expected to occur in that country. This ability to expand agricultural production is expected to moderate the price increase brought about by the expanded ethanol demand. For presenting our results, we focus on the last year of the projections, i.e., 2021/22.

Besides area expansion, agricultural output can be further increased by intensification of production in existing areas. Yield-price elasticity and double cropping are two different ways in which intensification of production can occur, though potentially driven by the same economic (and other) factors such as increasing commodity prices (in relation to production inputs) and relative land scarcity (due to competing activities or to physical restrictions in terms of availability and/or suitability). These factors in different combinations apply to all regions. For Brazil and the U.S. both yield-price elasticities and double crops are modeled explicitly whereas for other countries, intensification is modeled through yield-price elasticity. Both forms of intensification have the potential of lowering the addition or conversion of new areas to crop production, reducing land-use change (and the associated GHG emissions) that result from a given demand shock. A shortcoming of our modeling framework is the limitation of having double cropping as a method of intensification only included for Brazil and the United States. An expansion of the model to include double-cropping on a global scale would further reduce the land requirements after an increase of biofuel production. ${ }^{9}$

\footnotetext{
${ }^{9}$ Between 2004 and 2011, harvested area increased by 94 million ha whereas cropland only increased by 17.5 million ha.
} 


\section{Impact on the U.S. and Global Agricultural Sector}

The higher demand for ethanol increases ethanol wholesale prices by $3 \%$ relative to the baseline which results in an increase in ethanol production by $16.8 \%$. Because of the increased ethanol supply, gasoline retail prices decline by almost $3 \%$ relative to the baseline. The small increase in net imports of ethanol in the U.S. reflects the fact that the higher demand for ethanol is met by increased domestic production rather than increased imports. See the section "Changes in the U.S. Ethanol Sector" in the supplemental information for more detail.

The higher demand for ethanol increases the demand for corn used in the production of ethanol. U.S. corn used for ethanol goes up by $18 \%$ resulting in $3 \%$ increase in the price of corn. In response to the higher corn prices, domestic corn production goes up by $3.09 \%$ which is composed of a $2.91 \%$ increase in area harvested and a $0.18 \%$ increase in yield. Total domestic corn use (i.e., feed, food, and ethanol) increases by $6.57 \%$ because higher corn prices reduce feed use by $3.90 \%$ and food and other uses by $0.26 \%$ which only partially offset the increase in ethanol uses. There is a significant reduction in the net exports of corn. See section "U.S. Grain Sector" in the supplemental information for more details.

Higher corn prices and the increase in corn area by $3 \%$ bids land away from wheat, resulting in a decline in wheat area and production by $0.7 \%$. Lower wheat supplies increase the price of wheat by $1.5 \%$, which results in a reduction in food use, stocks and net exports. Feed use increases by $6 \%$ as wheat feed becomes less expensive relative to corn, despite the higher wheat prices. Similarly, in the case of barley, the demand for barley feed increases by $3 \%$ and the price of barley increases by over $2 \%$. The higher barley prices result in a decrease in food and stocks. In contrast to wheat, the area of barley increases as it does not face such strong competition because of regional differences for land from corn production.

As in the case of wheat, the increase in corn area comes at the expense of soybean harvested area, which leads to a $1.4 \%$ reduction in the production of soybeans. Soybean price increases by $5 \%$ while use declines by $1 \%$. Lower soybean supplies and a higher price lead to a $1 \%$ reduction in crush due to lower crush margins and a concomitant decline in the production of soybean oil and soybean meal. See the section "U.S. Soybean Complex" in the supplemental information for more detail.

Given that the higher U.S. demand for ethanol is met domestically, the impact on the world is muted especially in the case of sugarcane area and sugar prices. The increased demand for corn by the U.S. increases the world corn price by about $4 \%$ and increases corn area harvested in the world by $1.3 \%$. As corn area increases, this comes at the expense of area allocated to other crops, which decreases by $0.4 \%$ for soybeans and by $0.1 \%$ for both wheat and barley. As a result of the reduced supply, the prices of these crops increase relative to the baseline. See section "Global Price and Area Change" in the supplemental information for more detail.

\section{Impact on the Brazilian Agricultural Sector}

Brazil responds to the higher world prices by increasing area and production for corn, soybeans and wheat. The area expansion can be attributed to the need to partially replace the decrease in supply (exports) from the United States. Ceteris paribus, the generated excess demand for the rest of the world will push crop prices up and increase crop area in Brazil. Sugarcane area and sugar production in Brazil increase slightly in response to the small increase in the world ethanol and sugar prices (see Table 5 in Supplemental Materials). The regional distribution of the change in crop area, pasture and planted forest is presented in Table 2.

Taheripour et al. (2017b) attribute this in part to a global increase in double-cropping as well as the reduction in idle land and crop failures. 
Most of the increase in sugarcane area is in the Central West, which increases sugarcane area by 1,589 hectares, an increase of $0.09 \%$. In terms of the other crops, which include corn, soybeans, cotton, rice and dry beans, the largest increase is also in the Central West region with an increase of 72,164 hectares. The total area planted to first crops increases by 189,539 hectares. Similarly, the total area planted to second crops also increases by 121,000 hectares. While total area increase by 311,000 hectares, only 41,209 hectares more are used for agriculture (including crops, pasture, and planted forests). Table 2 indicates that some of the area expansion comes from pasture and forestland, which partially offsets the demand for additional land. The increase of cropped area into pasture is accommodated or feasible due to an increase in the intensity with which pastures are used, as evidenced by higher stocking rates (stock of cattle divided by pasture area). The largest levels of pasture-use intensification can be observed in the South region. In short, the possibility to substitute planted forests and to intensify pasture-based activities has the potential to reduce the levels of deforestation in the presence of high demand for crop land. While the change in stocking rates seem small, the sheer size of the pasture areas of the country imply that this is enough to accommodate the production of a nontrivial amount of beef.

\section{Impact on Global GHG Emissions}

Panel (a), Figure 3 represents the change in area due to an increase in U.S. biofuel production. Because the increase in 2008 version was 29.86 billion liters and the increase in the 2016 version was 10.82 billion liters, the data is normalized to an increase of 10 billion liters. The results presented under the current model include both the market-mediated responses and induced yield changes for the 2016 data and the market mediated responses for the 2008 data. The results suggest that for the majority of countries, with the exception of Mexico and Russia, as well as globally, the endogenous yield response reduces the area expansion due to the increase in U.S. ethanol. Thus, the effects on indirect land-use change are going to be reduced since less area is needed. Overall, the area expansion is $0.14 \%$ and $0.26 \%$ per 10 billion liters for the 2016 and 2008 model respectively. Note that those results are entirely driven by the CARD/FAPRI Model and that the 2008 data from the 2008 CARD/FAPRI Model does not include the yield improvements triggered by higher commodity prices (Table 3 ). The results focus on the scenario that includes the market mediating effects as well as the yield improvements. The tables include the results for the market-mediating scenario as well. ${ }^{10}$

Emissions using mean carbon coefficients are $13.1 \mathrm{~g} \mathrm{CO}_{2} \mathrm{MJ}^{-1}$ (Table 3). Lower and upper bounds of GHG emissions from the 2016 baseline and scenario results in land-use emissions are ranging from 9.7 to $23.9 \mathrm{~g} \mathrm{CO}_{2} \mathrm{MJ}^{-1}$ (Table 4). Not including the Brazil model, i.e., summing the area and production of the six regions and not taking regional differences into account, would increase mean emissions to $17.8 \mathrm{~g} \mathrm{CO}_{2}$ $\mathrm{MJ}^{-1}$. Thus, including sub-national modeling of Brazilian agriculture reduces overall emissions by $26 \%$ compared to the estimates without the Brazil model. This indicates that emissions are lower if Brazil is modeled at the sub-national level. This can be attributed to more restrictive (i.e., lower) expansion in the biomass-rich Amazon biome. Our estimates are consistent with the data by Taheripour et al. (2017b) which calculated $12 \mathrm{~g} \mathrm{CO}_{2}$-e $\mathrm{MJ}^{-1}$ for corn ethanol using the GTAP-BIO model. As aforementioned, Dumortier et al. (2011) based their emission estimates on cropland only. If we ignore pasture in our current model, emission estimates slightly increase from 17.8 to $18.2 \mathrm{~g} \mathrm{CO}_{2} \mathrm{MJ}^{-1}$.

To evaluate the emissions from the corn ethanol expansion in the context of the new model and the work published in Dumortier et al. (2011), we proceed in two steps. In a first step, we take the 2016 data and

\footnotetext{
${ }^{10}$ Note that the 2008 analysis did not include pasture data and thus, in the current model with pasture, the 2008 results are not included.
} 
use it in the 2008 GHG Model. This results in emissions of $23.2 \mathrm{~g} \mathrm{CO}_{2}-\mathrm{e} \mathrm{MJ}^{-1}$ (Table 3). Note that there are three big difference in models: First, the 2008 GHG Model assesses emissions using 513 spatial units instead of using the raster dataset provided by FAO (2000) and Monfreda et al. (2008). Second, the 2016 CARD/FAPRI Model has an endogenous yield-price relationship whereas the work published in Dumortier et al. (2011) used an ad-hoc approach for yield improvements. And lastly, the 2008 GHG Model only incorporates 10 crops instead of $14 .{ }^{11}$

In a second step, we use the 2008 data in the 2016 GHG Model. Dumortier et al. (2011) use data that was generated for the 2008 baseline and was first published in Hayes et al. (2009). The scenario "Market" includes the linkage between the crude oil price and the variable production costs. Because the ethanol scenario analyzed in Dumortier et al. (2011) was triggered by a higher crude oil price, linking oil price to production costs reduces the land expansion in the scenario since production costs are higher. The scenario "Market + Yield" was an ad-hoc calculation that assumed crop production to remain constant but a higher commodity yields triggered by higher prices. Recall that Dumortier et al. (2011) found that market responses and yield increases associated with an increase in biofuel production results in emissions of 65.1 and 14.5 $\mathrm{g} \mathrm{CO}_{2} \mathrm{MJ}^{-1}$ (Table 3), respectively. For the scenario with the market mediating responses only, the mean emissions are $25.8 \mathrm{~g} \mathrm{CO}_{2} \mathrm{MJ}^{-1}$ compared to $23.8 \mathrm{~g} \mathrm{CO}_{2} \mathrm{MJ}^{-1}$ for the 2016 data.

A peculiar result emerges if the 2008 yield improvement data is used in the 2016 model. Emissions from corn ethanol expansion are close to zero, i.e., $0.6 \mathrm{~g} \mathrm{CO}_{2} \mathrm{MJ}^{-1}$. This result warrants a close analysis. The initial 2008 data includes market mediating effects but no yield improvements. Those were incorporated in an ad-hoc manner in the 2008 GHG Model. Thus, the difference in emissions for the 2008 data and the two models can be attributed to differences in emission factors. A closer look at figures presented in Dumortier et al. (2011) reveals that the yield elasticities used were such that in some regions, crop area in the ethanol expansion scenario is below the baseline resulting in less land-use in the scenario than the baseline. Using 2008 yield data in the current model thus results in extremely low carbon emissions. This highlights the importance of a solid modeling of the yield-price relationship as was done in the current CARD/FAPRI Model. The emissions of $0.6 \mathrm{~g} \mathrm{CO}_{2} \mathrm{MJ}^{-1}$ are unrealistic in the opinions of the authors and are the result of too high yield-price elasticities used in Dumortier et al. (2011).

Panel (b), Figure 3 illustrates the emissions/sequestration by country/region. Only the emissions in Brazil are affected by including the Brazil Model. The results illustrate that the inclusion of the Brazil Model significantly reduces emissions from land-use change. The results show that including yield changes in response to modifications in price levels affects the results. In particular, the responses to the exogenously imposed increase in biofuel demand in terms of land use change and associated GHG emissions are mitigated by the possibility of increasing output levels in a given area. It is difficult to establish the exact contribution of the possibility to intensify production as this is one of several changes between the model versions used among studies. This finding is consistent with the literature reviewed in previous sections.

\section{Effects of Sub-National Modeling of Brazil}

The causes for the emission differences by incorporating the sub-national model of Brazilian agriculture are twofold: First, incorporating the 2nd crops of barley, safrinha corn, and wheat into the analysis reduces the difference between crop area required. ${ }^{12}$ Not including double cropping would yield an area difference of 311,000 hectares for crops alone (Table 2). Including double cropping reduces the area difference between the two scenarios to 189,539 hectares.

\footnotetext{
${ }^{11}$ The crops not included are cotton, palm kernel, oats, and rye.

${ }^{12}$ Wheat and barley are not included in the competition for land because they are assumed to grow on a different season (but not on the same land as first crops).
} 
Pasture area as the second reason for the emissions difference is more important than the double cropping. Previous versions of the CARD/FAPRI Model did not model pasture area explicitly. That is, required pasture area for livestock was based on fixed stocking rates that do not change between scenarios. The sub-national Brazil Model is an improvement in the sense that stocking rates in Brazil are modelled explicitly based on returns of pasture and other activities. Due to higher commodity prices - which translates into higher feed prices - livestock populations in Brazil are reduced. This reduction leads only to a small change in the pasture area - and thus emissions - in the aggregate model which assumes fixed stocking rates (Figure 4). In the sub-national model, the reduction in pasture is significant and is compensating in part for the increased emissions from cropland expansion. Using aggregate data in Brazil results in a reduction in pasture area by 26,690 ha whereas the sub-national model results in a reduction of 148,33 ha.

\section{Sensitivity Analysis with Regard to Global Sugar Markets}

The main feedstock for ethanol production in the Brazil is sugarcane. To assess the effects on land-use change in Brazil and globally, as well as the consistency and robustness of the model, we conducted a sensitivity analysis scenario run that increased global sugar consumption by $10 \%$ (we refer to this as the sugar scenario). This results in an increase in Brazilian sugarcane harvested area by $2.51 \%$. Total net used area increases by 47,934 hectares, which is comparable to the increase in area under the scenario where ethanol demand increases by $15 \%$ in the U.S. (we refer to this as the original scenario). There is a difference in the emissions profile associated with both changes for reasons explained below. The $15 \%$ increase in demand for U.S. ethanol results in mean emissions of $2.76 \mathrm{Mt} \mathrm{CO} 2-\mathrm{e}$ whereas the increase in sugar demand results in $7.30 \mathrm{Mt} \mathrm{CO} 2$-e. The large difference in emissions (compared to the similar difference in area) is due to the much larger land use changes for individual activities in this run, and to a lesser extent to different regions of the country being affected.

At the country level in Brazil, the increase in cropland area change is over twice as large in the sugar scenario as in the original scenario, both relative to the baseline. However the larger cropland area increase is mostly offset by a larger reduction in pasture areas in the sugar scenario when compared to the original scenario. This results in a very similar net increase relative to the baseline in both scenarios, as indicated previously.

These differences in terms of changes in cropland area are due to a couple of factors relating to the magnitude of the shock (scale) and to the commodities on which the excess demand was introduced into the modeling system. In terms of scale, a 10\% increase in global sugar consumption is a larger shock (in terms of tons of feedstock needed) than a $15 \%$ in U.S. ethanol consumption, and more land is needed to produce the additional feedstock. Additionally, the U.S. ethanol shock is quickly converted by the model into a corn shock (as most ethanol produced in the U.S. uses corn as a feedstock), whereas the sugar scenario is mainly a shock on sugarcane demand and on sugar beet demand to a lesser extent. The corn market is much larger than the sugar market, and involves many more countries than the sugar market, which is mostly dominated by Brazil (and thus is more akin to a shock concentrated in Brazil). Within Brazil and as expected, the model shows that the Southeast region is the region experiencing more abrupt land use changes with the additional demand for sugarcane.

The expansion of cropland into pasture results in positive levels of GHG emissions. Thus larger land use changes (of cropland and in particular sugarcane) associated with the sugar scenario will result in higher levels of emissions relative to the original scenario despite having a similar increase in area used for agricultural activities. 


\section{Conclusion}

The estimation of land-use change and its associated emissions have received a lot of attention from academics and policy makers over the last decades because of biofuels. Early research suggested that the indirect emissions are significant and hence, have a detrimental effect on the lifecycle emissions of biofuels. The research was partially based on models (including the CARD/FAPRI Model used in this paper) that were built to evaluate price and trade effects of agricultural policies and not necessarily area changes. This resulted over the subsequent years in significant research and improvements of those agricultural projection models with a detailed focus on modelling land-use change. This was important because policy makers based their decisions on the output of those models to evaluate biofuel GHG emissions for example. Due to rising concerns about climate change and GHG emissions, the application of those models goes beyond biofuels but can evaluate other (climate) policies in the future.

This paper contributes to the literature by highlighting the care that must be given to modelling global land-use change. We incorporate a sub-national model of Brazilian agriculture which explicitly models double-cropping, pasture expansion/reduction due to changes in livestock size and stocking rate, as well as competition among crops and pasture specific to different regions in Brazil. Previous literature has shown that yield and stocking rate changes have significant effects on land-use allocation estimates. The potential for intensification of crops and livestock production in countries like Brazil reduces the pressure for deforestation of natural areas. This paper provides a review of several of the major factors that will determine the need to incorporate additional land to production in response to a demand increase due to, for example, biofuel policies. Policy makers and other stakeholders need to be made aware that modelling land-use at the global level and projecting it into the future is a highly complex undertaking. Results across models and even within the same model (as demonstrated in this paper) can vary based on improvements and new research. Work in this line is incipient and clearly more research is needed to truly understand the implications of adding this competition, different levels of policy enforcement, and potentials for yield (both in terms of crops and pastures) on evaluations of agricultural price change, land use change, and environmental impacts.

\section{Acknowledgements}

This paper is based upon research funded by the United States Department of Agriculture's National Institute of Food and Agriculture/Agriculture and Food Research Initiative, Award number 2011-67023-30889 as well as a cooperative agreement between the Center for Agricultural and Rural Development at Iowa State University and the Office of the Chief Economist, Climate Change Program Office Cooperative, United States Department of Agriculture. The funding sources have no involvement in the study design, data collection and analysis, or in any other aspects of the research or paper publication. The views expressed in this article are those of the authors and do not necessarily reflect the views or policies of the U.S. Department of Agriculture. 


\section{References}

Aguiar, A. P. D., Câmara, G., Escada, M. I. S., 2007. Spatial statistical analysis of land-use determinants in the Brazilian Amazonia: Exploring intra-regional heterogeneity. Ecological Modelling 209 (2-4), 169188.

Alix-Garcia, J., Gibbs, H. K., 2017. Forest conservation effects of brazil's zero deforestation cattle agreements undermined by leakage. Global Environmental Change 47, 201-207.

André Meloni Nassar, L. H., Granço, G., 2013. Comparing the trends and strength of determinants to deforestation in the Brazilian Amazon in consideration of biofuel policies in Brazil and the United States. Tech. rep., ICONE Institute for International Trade Negotiations.

Angelsen, A., Kaimowitz, D., 1999. Rethinking the causes of deforestation: Lessons from economic models. The World Bank Research Observer 14 (1), 73-98.

Arima, E. Y., Barreto, P., Arajo, E., Soares-Filho, B., 2014. Public policies can reduce tropical deforestation: Lessons and challenges from brazil. Land Use Policy 41, 465-473.

Arima, E. Y., Richards, P., Walker, R., Caldas, M. M., 2011. Statistical confirmation of indirect land use change in the Brazilian Amazon. Environmental Research Letters 6 (2), 024010.

Azevedo, A. A., ao, R. R., Costa, M. A., Stabile, M. C., Macedo, M. N., dos Reis, T. N., Alencar, A., SoaresFilho, B. S., , Pacheco, R., 2017. Limits of brazil's forest code as a means to end illegal deforestation. Proceedings of the National Academy of Sciences 114 (29), 7653-7658.

Barona, E., Ramankutty, N., Hyman, G., Coomes, O. T., 2010. The role of pasture and soybean in deforestation of the Brazilian Amazon. Environmental Research Letters 5 (2), 024002.

Barr, K., Babcock, B. A., Carriquiry, M. A., Nassar, A. M., Harfuch, L., 2011. Agricultural land elasticities in the united states and brazil. Applied Economic Perspectives and Policy 33 (3), 449-462.

CARB, 2014. Initial statement of reasons for proposed rulemaking: Proposed re-adoption of the low carbon fuel standard. Staff report, California Environmental Protection Agency Air Resources Board.

CARB, 2015. Calculating carbon intensity values from indirect land use change of crop-based biofuels. Staff report, California Environmental Protection Agency Air Resources Board.

Choi, J.-S., Helmberger, P. G., 1993. How sensitive are crop yields to price changes and farm programs? Journal of Agricultural and Applied Economics 25 (1), 237-244.

Cohn, A. S., Mosnier, A., Havlik, P., Valin, H., Herrero, M., Schmid, E., O’Hare, M., Obersteiner, M., 2014. Cattle ranching intensification in Brazil can reduce global greenhouse gas emissions by sparing land from deforestation. Proceedings of the National Academy of Sciences 111 (20), 7236-7241.

de Almeida, F. C., Arenas, J. M., Pereira, L. M., de Aguiar, A. P. D., da Costa Freitas, C., April 2007. Modeling forest conversion to pasture at the Arch of deforestation in the Brazilian Amazon through linear regression technique. Tech. rep., Anais XIII Simpósio Brasileiro de Sensoriamento Remoto INPE, Florianópolis, Brasil, p. 6557-6564. 
de Oliveira Silva, R., Barioni, L. G., Hall, J. A. J., Matsuura, M. F., Albertini, T. Z., Fernandes, F. A., Moran, D., 2016. Increasing beef production could lower greenhouse gas emissions in Brazil if decoupled from deforestation. Nature Climate Change 6, 493-497.

de Souza Ferreira Filho, J. B., Horridge, M., 2014. Ethanol expansion and indirect land use change in Brazil. Land Use Policy 36, 595-604.

de Souza Ferreira Filho, J. B., Ribera, L., Horridge, M., 2015. Deforestation Control and Agricultural Supply in Brazil . American Journal of Agricultural Economics 97 (2), 589-601.

Diniz, M. B., de Oliveira Junior, J. N., Neto, N. T., Diniz, M. J. T., 2009. Causas do desmatamento da amazônia: uma aplicação do teste de causalidade de granger acerca das principais fontes de desmatamento nos municípios da amazônia legal brasileira. Nova Economia 19 (1), 121-151.

Dumortier, J., Hayes, D. J., Carriquiry, M., Dong, F., Du, X., Elobeid, A., Fabiosa, J. F., Martin, P. A., Mulik, K., 2012. The effects of potential changes in United States beef production on global grazing systems and greenhouse gas emissions. Environmental Research Letters 7 (2), 024023.

Dumortier, J., Hayes, D. J., Carriquiry, M., Dong, F., Du, X., Elobeid, A., Fabiosa, J. F., Tokgoz, S., 2011. Sensitivity of carbon emission estimates from indirect land-use change. Applied Economic Perspectives and Policy 33 (3), 428-448.

Egbendewe-Mondzozo, A., Swinton, S. M., Kung, S., Post, M. W., Binfield, J. C., Thompson, W., 2015. Bioenergy supply and environmental impacts on cropland: Insights from multi-market forecasts in a great lakes subregional bioeconomic model. Applied Economic Perspectives and Policy 37 (4), 602-618.

Elobeid, A., Carriquiry, M., Dumortier, J., Rosas, F., Mulik, K., Fabiosa, J. F., Hayes, D. J., Babcock, B. A., 2013. Biofuel expansion, fertilizer use and GHG emissions: Unintended consequences of mitigation policies. Economics Research International Special Issue "Economics of Bioenergy” (708607).

Elobeid, A., Carriquiry, M., Fabiosa, J. F., 2012. Socioeconomic and environmental impacts of biofuels: Evidence from developing nations. Cambridge University Press, Ch. Implications of global ethanol expansion on Brazilian regional land use, pp. 171-190.

Faminow, M. D., 1997. Spatial economics of local demand for cattle products in Amazon development. Agriculture, Ecosystems \& Environment 62 (1), 1-11.

FAO, 2000. Food Insecurity, Poverty and Environment Global GIS Database (FGGD). http:// geonetwork3. fao.org/fggd/ accessed on 28 March 2017.

Gibbs, H. K., 2006. Olson's Major World Ecosytem Complexes Ranked by Carbon in Live Vegetation: An Updated Database Using the GLC2000 Land Cover Product. NDP-017b, doi: 10.3334/CDIAC/lue.ndp017.2006.

Goodwin, B. K., Marra, M. C., Piggott, N. E., Mueller, S., 2012. Is yield endogenous to price? an empirical evaluation of inter- and intra-seasonal corn yield response. Tech. rep., Agricultural and Applied Economics Association 2012 Annual Meeting.

Harfuch, L., Bachion, L. C., Moreira, M. M. R., André, Nassar, M., Carriquiry, M., 2017. Handbook of Bioenergy Economics, and Policy: Volume II, Modeling Land Use and Greenhouse Gas Implications. 
Springer, Ch. Empirical Findings from Agricultural Expansion and Land Use Change in Brazil, pp. 273302.

Hayes, D., Babcock, B., Fabiosa, J., Tokgoz, S., Elobeid, A., Yu, T.-H., Dong, F., Hart, C., Chavez, E., Pan, S., Carriquiry, M., Dumortier, J., 2009. Biofuels: Potential production capacity, effects on grain and livestock sectors, and implications for food prices and consumers. Journal of Agricultural and Applied Economics 41 (2), 465-491.

Hertel, T. W., Golub, A. A., Jones, A. D., O'Hare, M., Plevin, R. J., Kammen, D. M., 2010. Effects of US maize ethanol on global land use and greenhouse gas emissions: Estimating market-mediated responses. BioScience 60 (3), 223-231.

Houck, J. P., Gallagher, P. W., 1976. The price responsiveness of U.S. corn yields. American Journal of Agricultural Economics 58 (1), 731-734.

Huang, H., Khanna, M., 2010. An econometric analysis of u.s. crop yield and cropland acreage: Implications for the impact of climate change. Tech. rep., Agricultural and Applied Economics Association 2010 Annual Meeting.

IFPRI, 2010. Global trade and environmental impact study of the EU biofuels mandate. Final report, International Food Policy Institute.

IFPRI, 2011. Assessing the land use change consequences of European biofuel policies. Final report, International Food Policy Institute.

Keeney, R., 2010. Yield response and biofuels: Issues and evidence on the extensive margin. Tech. rep., Fourth World Congress of Environmental and Resource Economists.

Keeney, R., Hertel, T. W., 2009. The indirect land use impacts of United States biofuel policies: The Importance of acreage, yield and bilateral trade responses. American Journal of Agricultural Economics 91 (4), 895-909.

Kirby, K. R., Laurance, W. F., Albernaz, A. K., Schroth, G., Fearnside, P. M., Bergen, S., Venticinque, E. M., da Costa, C., 2006. The future of deforestation in the Brazilian Amazon. Futures 38 (4), 432-453.

Lapola, D. M., Schaldach, R., Alcamo, J., Bondeau, A., Koch, J., Koelking, C., Priess, J. A., 2010. Indirect land-use changes can overcome carbon savings from biofuels in Brazil. Proceedings of the National Academy of Sciences 107 (8), 3388-3393.

Lark, T. J., Salmon, J. M., Gibbs, H. K., 2015. Cropland expansion outpaces agricultural and biofuel policies in the United States. Environmental Research Letters 10, 044003.

Lyons, D., Thompson, R., 1981. The effect of distortions in relative prices on corn productivity and exports: a cross-country study. Journal of Rural Development 4 (1), 83-102.

Lywood, W., Pinkney, J., Cockerill, S., 2009. The relative contributions of changes in yield and land area to increasing crop output. Global Change Biology Bioenergy 1 (5), 360-369.

Macedo, M. N., DeFries, R. S., Morton, D. C., Stickler, C. M., Galford, G. L., Shimabukuro, Y. E., 2012. Decoupling of deforestation and soy production in the southern Amazon during the late 2000s. Proceedings of the National Academy of Sciences 109 (4), 1341-1346. 
Margulis, S., 2004. Causes of deforestation of the Brazilian Amazon. World Bank Working Paper 22, World Bank.

Martins, C. E. R., Barros, R. P., de Oliveira Junior, J. N., e Silva, A. L. F., Diniz, M. B., 2010. Causas dos determinantes da intensidade do desmatamento na Amazônia Legal: uma abordagem multinominal. Forum bnb 2010, Banco do Nordeste.

Menz, K. M., Pardey, P., 1983. Technology and U.S. corn yields: Plateaus and price responsiveness. American Journal of Agricultural Economics 65 (3), 558-562.

Meyer, S., Thompson, W., 2012. How do biofuel use mandates cause uncertainty? United States Environmental Protection Agency cellulosic waiver options. Applied Economic Perspectives and Policy 34 (4), $570-586$.

Meyers, W. H., Westhoff, P., Fabiosa, J. F., Hayes, D. J., 2010. The FAPRI global modeling system and outlook process. Journal of International Agricultural Trade and Development 6 (1), 1-19.

Monfreda, C., Ramankutty, N., Foley, J. A., 2008. Farming the planet: 2. geographic distribution of crop areas, yields, physiological types, and net primary production in they year 2000. Global Biogeochemical Cycles 22, 1-19.

Nepstad, D., McGrath, D., Stickler, C., Alencar, A., Azevedo, A., Swette, B., Bezerra, T., DiGiano, M., Shimada, J., da Motta, R. S., Armijo, E., Castello, L., Brando, P., Hansen, M. C., McGrath-Horn, M., Carvalho, O., Hess, L., 2014. Slowing Amazon deforestation through public policy and interventions in beef and soy supply chains. Science 344 (6188), 1118-1123.

Roberts, M. J., Schlenker, W., 2009. World supply and demand of food commodity calories. American Journal of Agricultural Economics 91 (5), 1235-1242.

Searchinger, T., Heimlich, R., Houghton, R. A., Dong, F., Elobeid, A., Fabiosa, J., Tokgoz, S., Hayes, D., Yu, T.-H., 2008. Use of u.s. croplands for biofuels increases greenhouse gases through emissions from land-use change. Science 319 (5867), 1238-1240.

Taheripour, F., Cui, H., Tyner, W. E., 2017a. Bioenergy and Land Use Change. American Geophysical Union. Wiley, Ch. An Exploration of agricultural land use change at the intensive and extensive margins: Implications for biofuels induced land use change.

Taheripour, F., Zhao, X., Tyner, W. E., 2017b. The impact of considering land intensification and updated data on biofuels land use change and emissions estimates. Biotechnology for Biofuels 10 (191).

Taheripour, F., Zhuang, Q., Tyner, W. E., Lu, X., 2012. Biofuels, cropland expansion, and the extensive margin. Energy, Sustainability and Society 2 (25), 1-11.

Thompson, W., Gerlt, S., Campbell, J. E., Kueppers, L. M., Lu, Y., Snyder, M. A., 2017. A cost of tractability? estimating climate change impacts using a single crop market understates impacts on market conditions and variability. Applied Economic Perspectives and Policy 39 (2), 346362.

Thompson, W., Meyer, S., Westhoff, P., 2010. The new markets for Renewable Identification Numbers. Applied Economic Perspectives and Policy 32 (4), 588-603. 
USDA, 2017. A life-cycle analysis of the greenhouse gas emissions of corn-based ethanol. Report prepared by icf under usda contract no. ag-3142-d-16-0243, U.S. Department of Agriculture.

Valin, H., Peters, D., van den Berg, M., Frank, S., Havlik, P., Forsell, N., Hamelinck, C., 2015. The land use change impact of biofuels consumed in the EU: Quantification of area and greenhouse gas impacts. Tech. Rep. BIENL13120, European Commission.

West, P. C., Gibbs, H. K., Monfreda, C., Wagner, J., Barford, C. C., Carpenter, S. R., Foley, J. A., 2010. Trading carbon for food: Global comparison of carbon stocks vs. crop yields on agricultural land. Proceedings of the National Academy of Sciences 107 (46), 1964519648.

Zycherman, A., 2016. Cultures of soy and cattle in the context of reduced deforestation and agricultural intensification in the Brazilian Amazon. Environment and Society 7 (1), 71-88. 


\begin{tabular}{lcccccccc}
\hline Region & $\epsilon_{r_{j}}^{A g, j}$ & Corn & Soybeans & Cotton & Rice & Dry beans & Sugarcane & Pasture \\
\hline South & 0.06 & 0.18 & 0.43 & 0.21 & 0.15 & 0.09 & 0.40 & 0.03 \\
South East & 0.07 & 0.20 & 0.43 & 0.21 & 0.12 & 0.10 & 0.40 & 0.05 \\
Center West & 0.18 & 0.20 & 0.48 & 0.25 & 0.13 & 0.10 & 0.43 & 0.11 \\
Amazon & 0.25 & 0.20 & 0.45 & 0.25 & 0.15 & 0.09 & 0.20 & 0.24 \\
Northeast Coast & 0.01 & 0.22 & $0.00^{*}$ & 0.20 & 0.13 & 0.10 & 0.39 & 0.01 \\
Northeast Cerrado & 0.10 & 0.19 & 0.44 & 0.22 & 0.13 & 0.10 & 0.40 & 0.07 \\
Brazil & 0.13 & & & & & & & \\
\hline
\end{tabular}

Table 1: Regional land-use elasticities and own-price elasticities for activities in Brazil model. For corn and dry beans, the values represented are for the 1st crop. The demand and supply elasticities of the models are based on a combination of methods and sources, ranging from literature reviews, estimations, and expert opinion. The model has been used and validated through a long list of peer-reviewed publications. The elasticities for land-use in Brazil are based in extensive work of empirical calibration, data observation and expert opinion conducted together by researchers at Iowa State University and the Brazilian Institute for International Trade Negotiations (ICONE). For work related to these elasticities and their use for analysis the reader is referred to Barr et al. (2011), Elobeid et al. (2012), and Harfuch et al. (2017). 


\begin{tabular}{|c|c|c|c|c|c|c|}
\hline & Sugarcane & Other Crops & 2nd Crops & Area Planted & Pasture & Area used \\
\hline \multicolumn{7}{|l|}{ Amazon Biome } \\
\hline Market & 0.0 & 31.4 & 17.7 & 49.1 & -31.4 & 0.0 \\
\hline Market + Yield & 0.0 & 22.0 & 13.5 & 35.4 & -22.0 & 0.0 \\
\hline \multicolumn{7}{|c|}{ Central-West Cerrados } \\
\hline Market & 2.3 & 102.4 & 109.4 & 214.2 & -55.0 & 49.8 \\
\hline Market + Yield & 1.6 & 70.6 & 76.3 & 148.5 & -36.0 & 36.2 \\
\hline \multicolumn{7}{|l|}{ Northeast Coast } \\
\hline Market & 0.3 & 9.0 & 0.0 & 9.4 & -7.6 & 1.7 \\
\hline Market + Yield & 0.2 & 6.8 & 0.0 & 7.0 & -5.8 & 1.2 \\
\hline \multicolumn{7}{|c|}{ North-Northeast Cerrados } \\
\hline Market & -0.1 & 39.4 & 4.7 & 44.0 & -39.3 & 0.0 \\
\hline Market + Yield & -0.1 & 28.1 & 3.3 & 31.4 & -28.0 & 0.0 \\
\hline \multicolumn{7}{|l|}{ South } \\
\hline Market & -0.2 & 56.4 & 40.9 & 97.1 & -55.3 & 0.9 \\
\hline Market + Yield & -0.2 & 40.1 & 28.7 & 68.6 & -39.2 & 0.7 \\
\hline \multicolumn{7}{|l|}{ Southeast } \\
\hline Market & -0.8 & 28.8 & 0.7 & 28.7 & -23.5 & 4.5 \\
\hline Market + Yield & -1.1 & 21.5 & -0.4 & 20.1 & -17.3 & 3.1 \\
\hline \multicolumn{7}{|l|}{ Total } \\
\hline Market & 1.5 & 267.4 & 173.5 & 442.4 & -212.0 & 56.9 \\
\hline Market + Yield & 0.4 & 189.1 & 121.5 & 311.0 & -148.3 & 41.2 \\
\hline
\end{tabular}

Table 2: Regional changes in the area (in 1,000 ha) used for agriculture in Brazil in 2021/2022. The area used represents the sum of sugarcane, other crops, and pasture. 


\begin{tabular}{|c|c|c|c|c|}
\hline \multirow[b]{2}{*}{ Data } & Market & Market + Yield & Market & Market + Yiel \\
\hline & \multicolumn{2}{|r|}{2008} & \multicolumn{2}{|r|}{2016} \\
\hline Ethanol increase in million liters & \multicolumn{2}{|r|}{29,859} & \multicolumn{2}{|r|}{10,818} \\
\hline Difference in Area Harvested $(*)$ & 6,076 & 569 & 1,655 & 1,201 \\
\hline Difference in Area Harvested per 10 bn L & 2,035 & 191 & 1,530 & 1,110 \\
\hline \multicolumn{5}{|l|}{ Dumortier et al. (2011) Model } \\
\hline Difference in Emissions & 1,231 & 274 & 220 & 159 \\
\hline $\mathrm{kg}$ of $\mathrm{CO} 2$ produced per liter of ethanol & 41.2 & 9.2 & 20.4 & 14.7 \\
\hline Over 30 Years & 65.1 & 14.5 & 32.2 & 23.2 \\
\hline \multicolumn{5}{|l|}{ Current model (no Brazil model, no pasture) } \\
\hline Difference in Emissions & 487 & 11 & 163 & 125 \\
\hline $\mathrm{kg}$ of $\mathrm{CO} 2$ produced per liter of ethanol & 16.3 & 0.4 & 15.0 & 11.5 \\
\hline Over 30 Years & 25.8 & 0.6 & 23.8 & 18.2 \\
\hline \multicolumn{5}{|l|}{ Current model with pasture (no Brazil) } \\
\hline Difference in Emissions & & & 157 & 122 \\
\hline $\mathrm{kg}$ of $\mathrm{CO} 2$ produced per liter of ethanol & & & 14.5 & 11.3 \\
\hline Over 30 Years & & & 23.0 & 17.8 \\
\hline \multicolumn{5}{|l|}{ Current model (complete) } \\
\hline Difference in Emissions & & & 110 & 90 \\
\hline $\mathrm{kg}$ of $\mathrm{CO} 2$ produced per liter of ethanol & & & 10.2 & 8.3 \\
\hline Over 30 Years & & & 16.1 & 13.1 \\
\hline
\end{tabular}

Table 3: Total land-use change emissions for the current model as well as the 2008 data as presented in Dumortier et al. (2011). For the current model, all coefficients are "mean" coefficients. Minimum and maximum coefficients are presented in table 4. (*) refers to changes in cropland areas and of pastureland where modeled. This also includes double cropping for U.S. wheat. 


\begin{tabular}{lrrrrr}
\hline & \multicolumn{2}{c}{ Market } & & \multicolumn{2}{c}{ Market + Yield } \\
\cline { 2 - 3 } & Min. & Max. & & Min. & Max. \\
\hline Current model (no Brazil, no pasture) & & & & \\
Difference in Emissions & 122.3 & 298.6 & 91.3 & 226.6 \\
kg of CO2 produced per liter of ethanol & 11.3 & 27.6 & 8.4 & 20.9 \\
Over 30 Years & 17.9 & 43.6 & 13.3 & 33.1 \\
Current model with pasture (no Brazil) & & & & \\
Difference in Emissions & 121 & 293 & 91.1 & 225.0 \\
kg of CO2 produced per liter of ethanol & 11.1 & 27.1 & 8.4 & 20.8 \\
Over 30 Years & 17.6 & 42.7 & 13.3 & 32.9 \\
Current model (complete) & & & & \\
Difference in Emissions & 84 & 203 & & 66.1 & 163.4 \\
kg of CO2 produced per liter of ethanol & 7.8 & 18.7 & 6.1 & 15.1 \\
Over 30 Years & 12.3 & 29.6 & 9.7 & 23.9 \\
\hline
\end{tabular}

Table 4: Minimum and maximum land-use change emissions for the current (2016) model. 


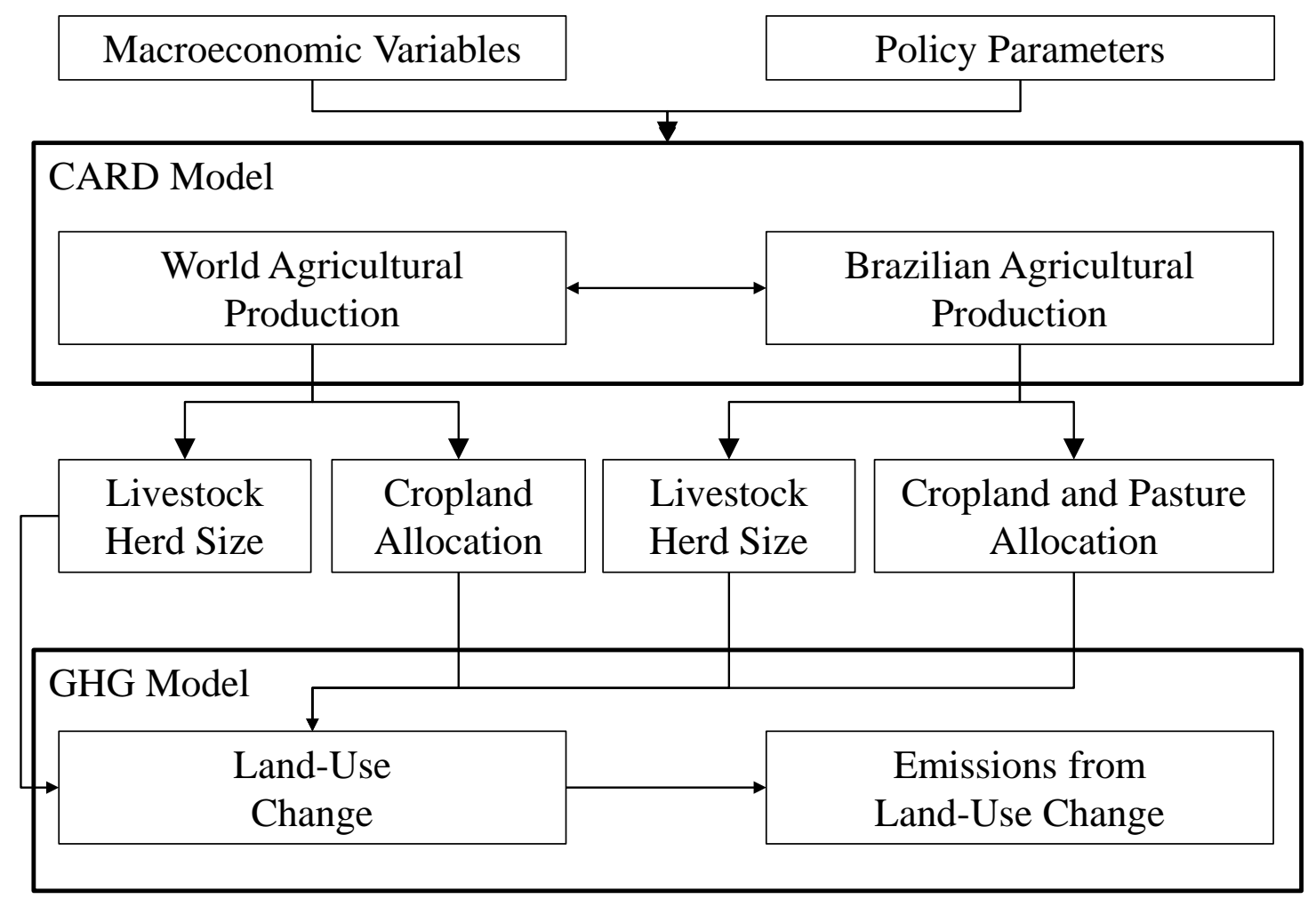

Figure 1: Overview of the FAPRI/CARD Model and its interaction with the GHG Model. 


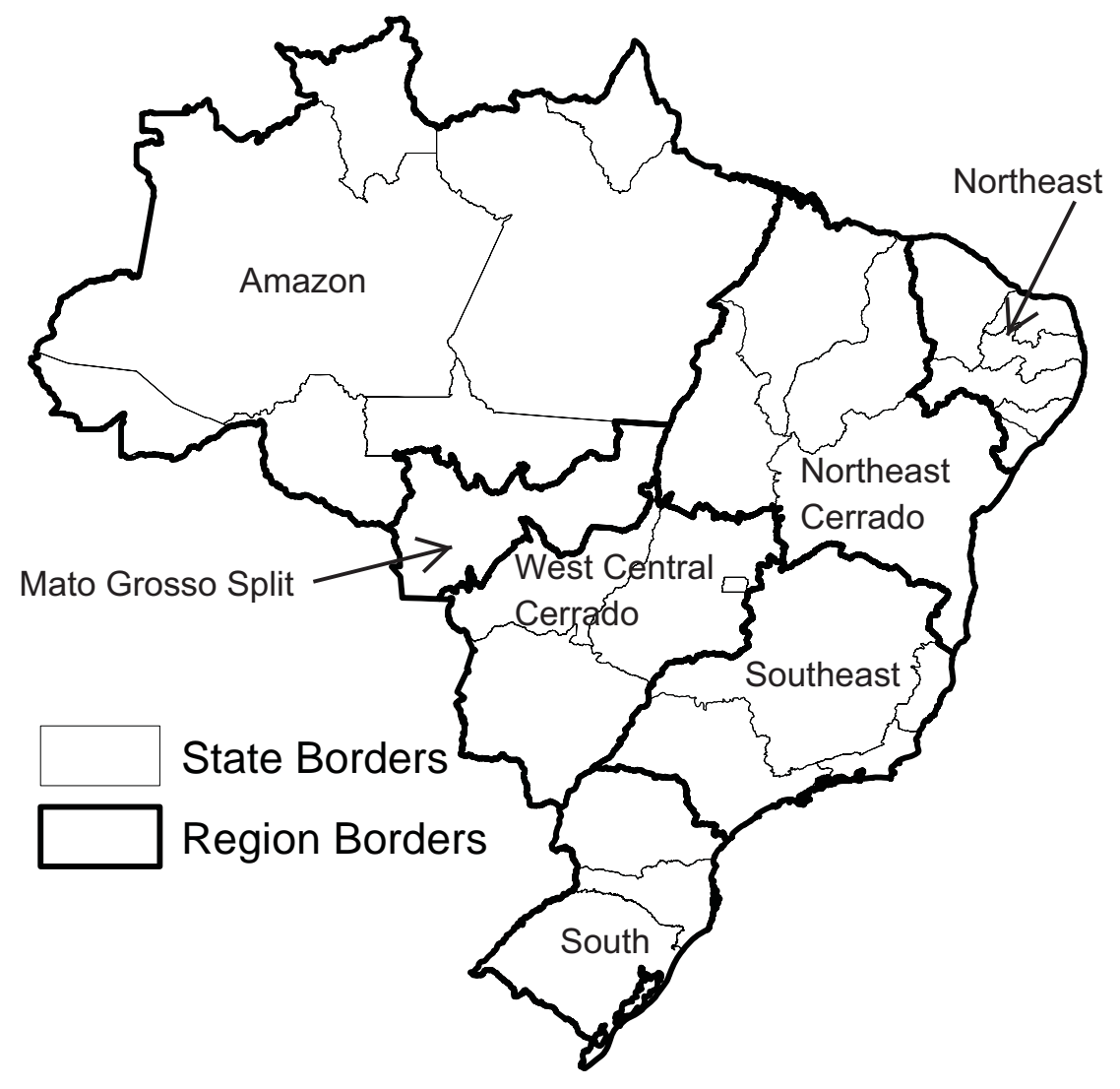

Figure 2: Regional Disaggregation of the CARD/FAPRI Brazil Model. Region 1: South (Rio Grande Do Sul, Santa Catarina, Parana), Region 2: Southeast (Sao Paulo, Rio de Janeiro, Espirito Santo, Minas Gerais), Region 3: Center West Cerrado (Mato Grosso Do Sul, Goias, Distrito Federal, Mato Grosso), Region 4: Amazon Biome (Rondonia, Amazonas, Para, Roraima, Amapa, Acre, Mato Grosso), Region 5: Northeast (Ceara, Paraiba, Rio Grande Do Norte, Pernambuco, Alagoas, Sergipe), and Region 6: North-Northeast Cerrado (Tocantins, Bahia, Maranhao, Piaui) 


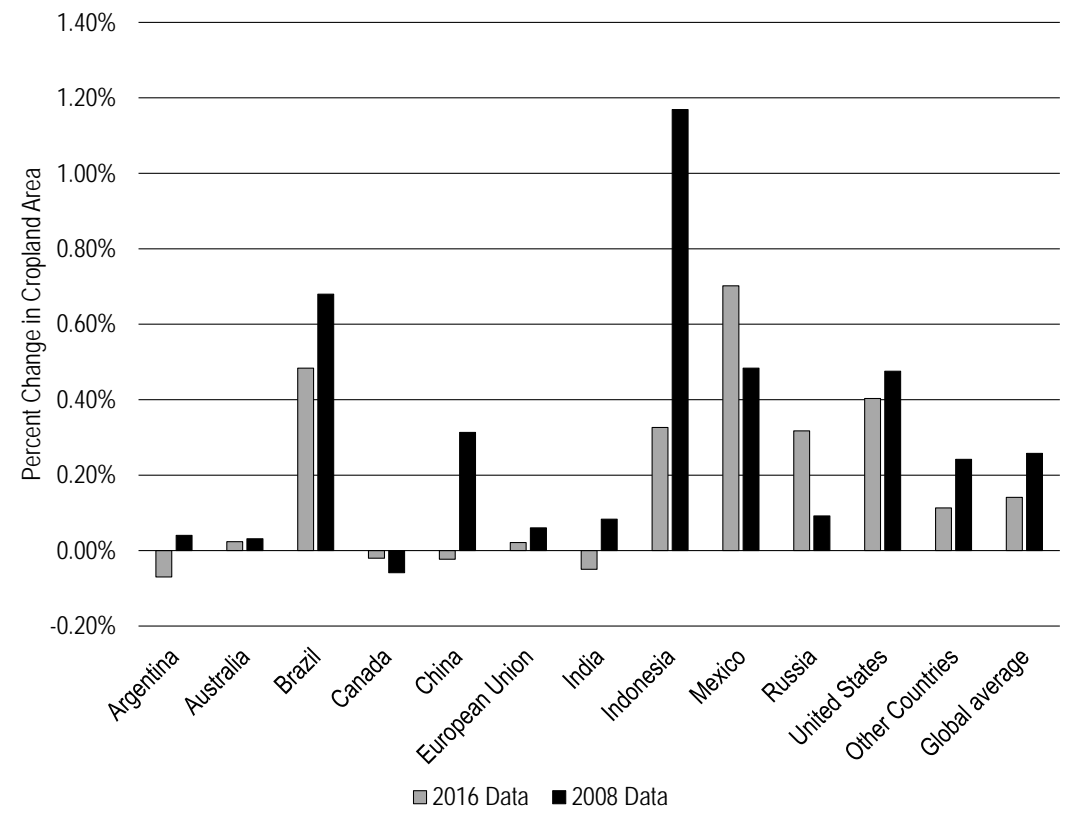

(a)

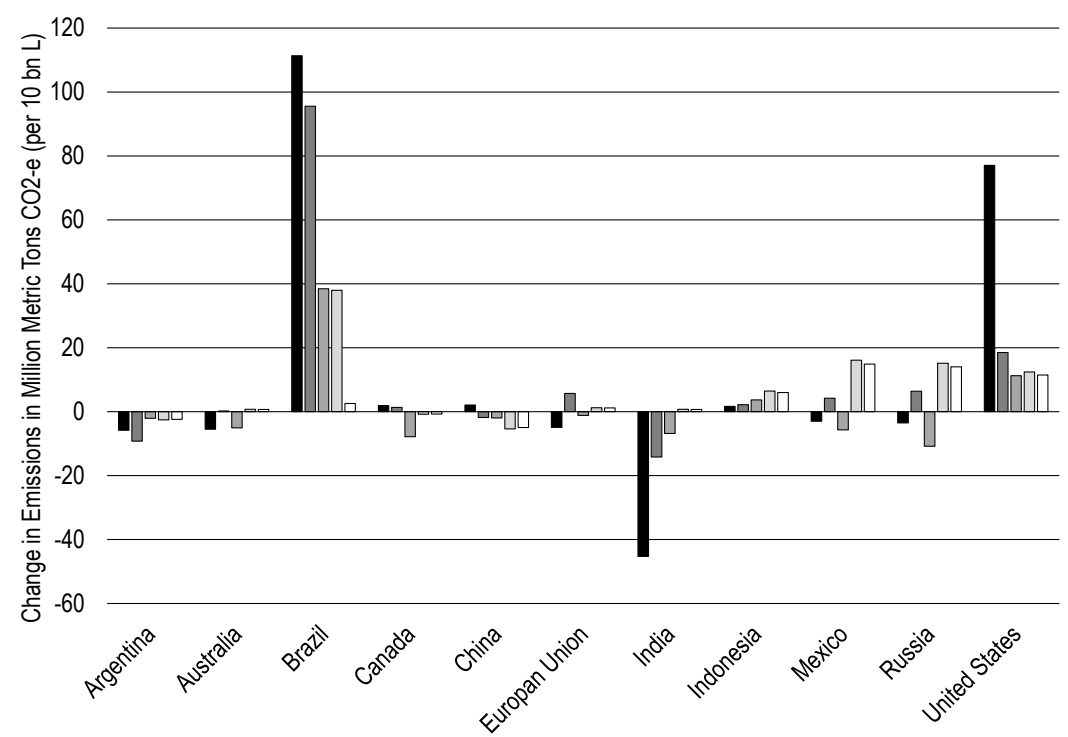

- AEPP 2011 Model, 2008 Data $\square$ AEPP 2011 Model, 2016 Data $\square 2016$ Model, 2008 Data $\square 2016$ Model, Data (no Brazil) $\square 2016$ Model, Data (with Brazil)

(b)

Figure 3: Panel (a): Comparison of area change between the 2008 and 2016 by country. Panel (b) Land-use change emissions in millon metric tons of $\mathrm{CO}_{2}$-e by country. Both figures are normalized to 10 billion liters. 


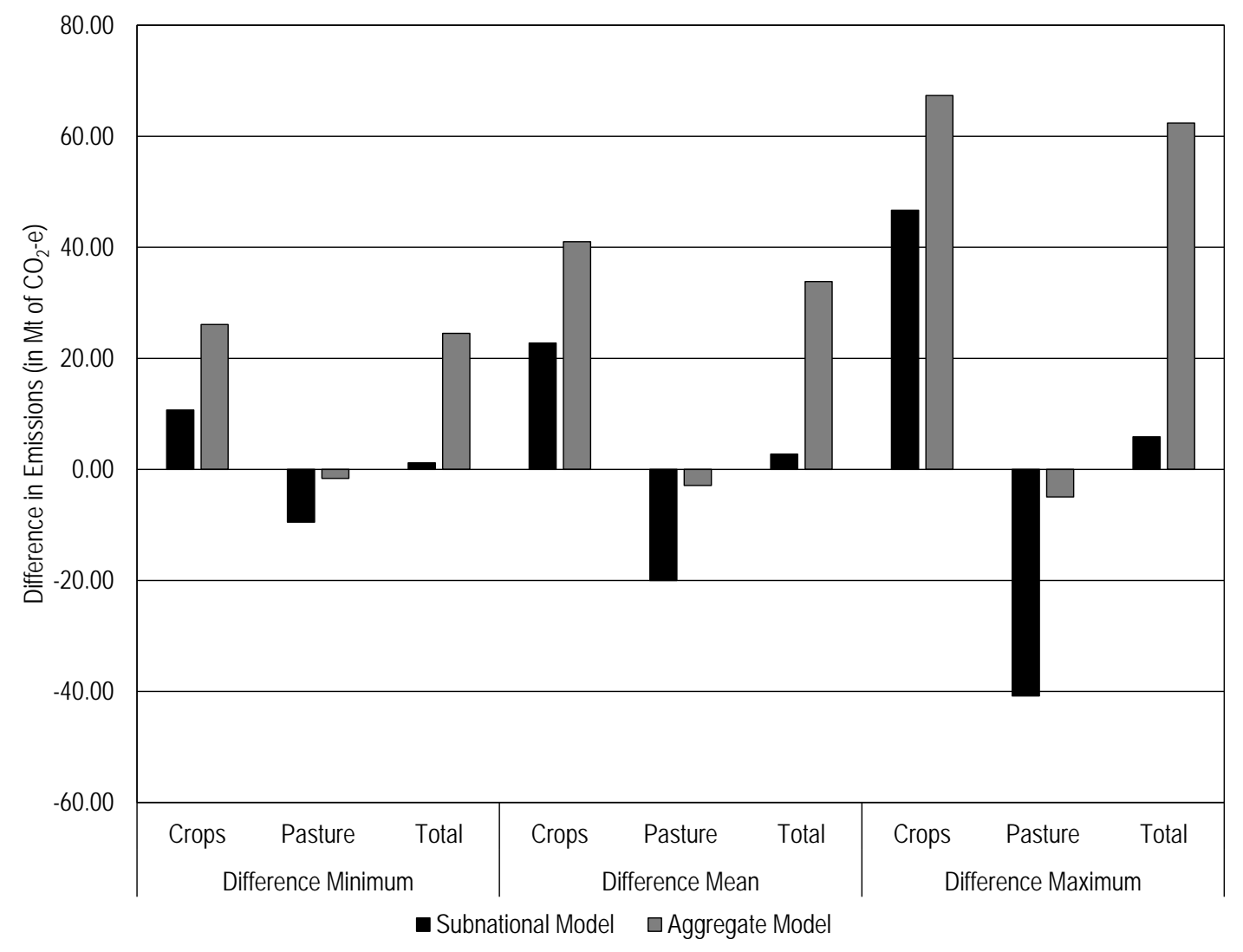

Figure 4: Effects of incorporating the sub-national Brazil model into the CARD/FAPRI Model for the minimum, mean, and maximum carbon coefficients. 